\title{
Kontribusi Perempuan Dalam Peningkatan Usaha Peternakan Sapi Potong Diera Modernisasi di Kelurahan Datara Kecamatan Malakaji Kabupaten Gowa
}

\author{
The Contribution of Women In Increasing Business a Cow In The Era of \\ Modernization in the Village Datara Subdistrict Malakaji District of Gowa \\ Mursidin*, Andi Suarda \\ Program Studi Ilmu Peternakan Fakultas Sains \& Teknologi Universitas Islam Negeri Alauddin \\ Makassar Jl. H. M. Yasin Limpo No. 36 Gowa, Telp. (0411) 5622375 \\ *Korespondensi E-mail : mursidin.natsir@uin-alauddin.ac.id
}

\begin{abstract}
ABSTRAK
Penelitian ini bertujuan untuk mengetahui sejauh mana kontribusi perempuan dalam meningkatkan usaha peternakan sapi potong di Kel. Datara Kec. Malakaji Kab. Gowa. Metode yang digunakan dalam penelitian ini yaitu dengan cara FGD (Focus Group Discussion) dimana dalam FGD ini dilakukan proses wawancara secara langsung terhadap perempuan yang berprofesi sebagai peternak sapi potong serta instansi dan tokoh adat daerah penelitian. Yang dimaksud wawancara adalah proses memperoleh keterangan atau informasi untuk tujuan penelitian/pengamatan dengan cara tanya jawab kepada responden dengan menggunakan alat interview guide atau panduan wawancara. Hasil yang dicapai pada penelitian ini adalah kontribusi perempuan dalam pemeliharaan mengontrol dan memberikan makanan pada ternak sebanyak dua kali sehari yakni pada pagi hari pukul 07.00 WITA dan sore hari pada pukul 16.30 WITA, hal ini mereka lakukan setiap harinya. Namun ada beberapa peternak yang memilih tidak mengandangkan ternaknya, mereka hanya melepaskan di area persawahan dengan tujuan agar ternaknya mampu memenuhi kebutuhan hijauannya. Ketidaktahuan menggunakan media elektronik seperti handpone mengurangi pengetahuan peternak tentang pemasaran ternak secara online, mereka masih memilih memasarkan secara tatap muka atau bertemu langsung dengan pembeli atau pelanggan maupun pedagang besar. kontribusi perempuan dalam budidaya ternak sapi potong yang ada di Kelurahan Datara, sangat berperan dalam pengambilan keputusan seperti halnya pembeliaan dan pemilihan bibit ternak, penjualan ternak serta pemanfaatan uang hasil penjualan ternak, dalam hal ini peran perempuan lebih mendominasi dalam pengembilan keputusan.
\end{abstract}

Kata kunci: Kontribusi, Perempuan, Peternak, Sapi Potong

\footnotetext{
ABSTRACT

This study attempts to understand the extent of the contribution of women in improving animal husbandry beef in village Datara sub-district Malakaji district 
Gowa. Methods used in research is in a focus group discussion (FGD) where in the interviews were done directly against women work as office and beef farmers and figures research areas. What is an interview the process of obtaining information for research purposes/observations by means integration to respondents by the use of a the interview or interview guidelines. The results to research this is the contribution of women in maintenance controls and give food in livestock twice a day in morning at 07.00 am and afternoon in $4.30 \mathrm{pm}$, this they do every day. But there some farmers who choose not to ground their flocks, they only release in a rice-growing area with the aim that their flocks able to fulfill a need forage. Ignorance of using electronic media like phone reduce knowledge about marketing online cattle farmers, they still preferring markets better for you in face to face or directly meet with a buyer or large customers and traders. The contribution of women in the cultivation of cattle production that is in datara, urban village was instrumental in decision making as well as the purchase and selection of, livestock calf the sale of cattle as well as the use of money the sale of cattle, in this role of women is more dominant in decision.

Keywords:, Contribution, cattle farmers, women.

\section{PENDAHULUAN}

Ternak sapi, khususnya sapi potong merupakan salah satu sumber daya penghasil bahan makanan berupa daging yang memiliki nilai ekonomi tinggi dan penting artinya didalam kehidupan masyarakat. Sebab seekor sapi atau kelompok ternak sapi bisa menghasilkan berbagai macam kebutuhan, terutama sebagai bahan makanan berupa daging. Menurut Mariyono dkk (2010) bahwa sapi potong termasuk dalam komponen usaha yang cukup berperan dalam agribibisnis pedesaan, utamanya dalam sistem integrasi dengan subsektor pertanian lainnya, sebagai rantai biologis dan ekonomis sistem usaha tani.

Perkembangan usaha sapi potong didorong oleh permintaan daging yang terus menerus meningkat dari tahun ke tahun dan timbulnya keinginan sebagian besar peternak sapi untuk menjual sapi-sapinya dengan harga yang lebih pantas. Perkembangan usaha sapi potong juga tidak lepas dari upaya pemerintah yang telah mendukung. Kondisi ini dapat menjadi motivasi dari para peternak untuk lebih mengembangkan usaha peternakan sapi potong sebagai upaya pemenuhan permintaan dan peningkatan pendapatan masyarakat (Siregar, 2008).

Kegiatan usaha produktif sub-sektor peternakan senantiasa melibatkan gender perempuan dalam pelaksanaan usaha tani, terutama usaha tani keluarga. Upaya melibatkan gender perempuan dalam kegiatan usaha tani-ternak merupakan salah satu upaya 
peningkatan keamanan ekonomi keluarga dan efisiensi pemanfaatan sumberdaya lokal serta meningkatkan status gender perempuan dalam kegiatan sektoral. Keterlibatan kaum perempuan dalam kegiatan usaha tani-ternak merupakan upaya meningkatkan kekuatan nilai input yang disumbangkan dalam proses produksi dan proses pengambilan keputusan. Tambahan penghasilan dari perempuan dalam ekonomi rumah tangga sangat penting dalam menunjang ekonomi keluarga. (Abdullah dan Amrawati, 2008).

Kelurahan Datara Kecamatan Malakaji Kabupaten Gowa merupakan salah satu wilayah yang memiliki populasi ternak yang cukup beragam jenisnya. Dalam penelitian ini, peneliti tertuju kepada komoditi sapi potong, dimana para wanita muda maupun ibu-ibu rumah tangga mengatur waktu mereka dalam memelihara ternak sapi potong, dalam hal ini para perempuan beternak untuk memenuhi kebutuhan ekonomi mereka, khasus yang terjadi yaitu kontribusi serta ide dan gagasan perempuan dalam sistem pemeliharaan masih tergolong sangat minim, mereka belum bisa memanfaatkan teknologi yang ada saat ini, seperti halnya mendapatkan informasi melalui kominikasi, produk obat obatan dari pabrik serta vitamin yang saat ini banyak digunakan oleh peternak.

Penyuluh daerah setempat telah berkomunikasi secara intensif dalam hal pemberian informasi dan sumbangan pemikiran dalam beternak sapi potong secara intensif, namun hal tersebut belum ada ketertarikan untuk menggunakannya. Dalam era modernisasi saat ini peternak telah banyak memanfaatkan media teknologi dan informasi untuk menunjang peningkatan usaha peternakannya, namun lain halnya yang dilakukan oleh perempuan yang berprofesi sebagai peternak yang ada di Kelurahan Datara Kecamatan malakaji Kabupaten Gowa yang masih menggunakan tradisi nenek moyang mereka dalam memelihara ternaknya.

\section{METODE PENELITIAN}

\section{Waktu dan Tempat Penelitian}

Penelitian ini dilaksanakan pada bulan Desesmber 2019 sampai Januari 2020 bertempat di Kelurahan Datara, Kecamatan Malakaji, Kabupaten Gowa. Penetuan pada lokasi penelitian ini karena Kelurahan Datara merupakan salah satu sentra populasi sapi potong di daerah Kabupaten Gowa.

\section{Jenis Penelitian}


Jenis Penelitian yang digunakan adalah penelitian kualitatif berupa fakta-fakta atau kejadian di lokasi penelitian yang berupa kalimat atau pernyataan yang sesuai dengan kebutuhan dalam penelitian ini.

\section{Populasi dan Sampel}

Penentuan populasi dan sampel dalam penelitian ini adalah secara sengaja (purposive) kepada peternak khususnya perempuan, tokoh-tokoh adat, dan aparat pemerintah di Kelurahan Datara Kecamatan Malakaji, Kabupaten Gowa.

\section{Metode Pengumpulan Data}

Metode pengumpulan data yang dilakukan pada penelitian di Kelurahan Datara Kecamatan Malakaji Kabupaten Gowa adalah dengan cara FGD (Focus Group Discussion) dimana dalam FGD ini dilakukan proses wawancara secara langsung terhadap perempuan yang berprofesi sebagai peternak sapi potong serta instansi dan tokoh adat daerah penelitian. Yang dimaksud wawancara adalah proses memperoleh keterangan atau informasi untuk tujuan penelitian/pengamatan dengan cara tanya jawab kepada responden dengan menggunakan alat interview guide (panduan wawancara).

\section{Instrumen Penelitian}

Kegiatan yang dilakukan pada penelitian mengenai Kontribusi Perempuan Dalam Usaha Peternakan Sapi Potong di Era Modernisasi di Kelurahan Datara, Kecamatan Malakaji, Kabupaten Gowa adalah FGD (Focus Group Discussion). FGD merupakan suatu diskusi yang dilakukan secara sistematis dan terarah mengenai suatu masalah tertentu. FGD berfungsi sebagai satu-satunya metode penelitian atau metode utama untuk pengumpulan data dalam penelitian.

\section{Analisis Data}

Analisis data yang digunakan pada penelitian ini yaitu analisis domain, analisis domain digunakan untuk memperoleh gambaran secara menyeluruh tentang situasi sosial yang sedang diteliti. Data diperoleh dari observasi dan wawancara dengan menggunakan kuisioner berupa pertanyaan secara mendalam (In depth Interview). Hal ini sesuai dengan pendapat Putra (2014) bahwa ada 4 model dalam analisis data penelitian kualitatif yaitu analisis domain, analisis taksonomi, analisis kompensial dan analisis tema budaya. 


\section{HASIL DAN PEMBAHASAN}

\section{Kontribusi Perempuan Beternak Sapi Potong di Era Moderenisasi}

1. Kontribusi Perempuan dari Sistem Pemeliharaan Ternak Sapi Potong

Memelihara sapi sangat menguntungkan, karena tidak hanya menghasilkan daging atau susu, tetapi juga menghasilkan pupuk kandang dan sebagai potensi tenaga kerja. Sapi potong sebagai penghasil daging, persentase karkas ( bagian yang dapat dimakan ) cukup tinggi, yaitu berkisar antara 45\% - 55\% yang dapat dijual pada umur 4-5 tahun (Rianto dan Purbowati 2009).

Berdasarkan hasil wawancara diketahui bahwa keinginan masyarakat untuk menjadikan usaha peternakan maju di Kelurahan Datara masih rendah karena sebagian besar hanya menjadikan ternak sebagai pekerjaan sampingan sedangkan pekerjaan pokoknya adalah bertani. Kontribusi perempuan dalam pemeliharaan mengontrol dan memberikan makanan pada ternak sebanyak dua kali sehari yakni pada pagi hari pukul 07.00 WITA dan sore hari pada pukul 16.30 WITA, hal ini mereka lakukan setiap harinya. Namun ada beberapa peternak yang memilih tidak mengandangkan ternaknya, mereka hanya melepaskan di area persawahan dengan tujuan agar ternaknya mampu memenuhi kebutuhan hijauannya.

Peternak yang memiliki kandang melakukan pembersihan pada pukul 10.30 WITA namun hal ini tidak mutlak dilakukan setiap hari, mereka melakukan pembersihan kandang berselang sehari sebab ternak yang dikandangkan hanya pada saat setelah diberi pakan hijaun setelah itu ternak dilepas untuk mencari makan sendiri sehingga feses yang ada di kandang tidak terlalu banyak. Kegiatan ini merupakan aktivitas dari kontribusi perempuan yang memiliki ternak sapi potong di Kelurahan Datara. Hal ini sesuai dengan hasil Penelitian Bonewati (2016) bahwa perempuan mengontrol aktivitas dalam memandikan ternak setiap hari pada pagi hari yakni pukul 10.00 WITA. Namun aktivitas ini tidak dilakukan oleh semua perempuan melainkan sebagian besar dibantu oleh anggota keluarga lainnya. Demikian halnya dalam aktivitas pembersihan kandang yang dilakukan setiap hari pada pukul 10.00 WITA.

2. Penjualan Ternak Sapi potong Menggunakan Media teknologi 
Moderenisasi memberikan perubahan dalam kehidupan manusia serta memberikan kemudahan dalam hal penggunaan media dan teknologi, pemasaran melalui media masa saat ini seperti contohnya penjualan ternak secara online yang sedang marak di zaman ini (Mahmuda, 2015).

Berdasarkan hasil wawancara bahwa kurangnya rasa ingin tahu masyarakat khususnya peternak dan ketidaktahuan menggunakan media elektronik seperti handpone mengurangi pengetahuan peternak tentang pemasaran ternak secara online, mereka masih memilih memasarkan secara tatap muka atau bertemu langsung dengan pembeli atau pelanggan maupun pedagang besar.

Adapun Tanggapan yang dilontarkan dari salah satu peternak bahwa online shop tidak dapat dipercaya sepenuhnya tentang keaslian barang yang dijual. Mereka masih sangat percaya dengan system pemasaran yang ia lakukan seperti contoh pedagang besar dan pedagang pengumpul serta konsumen yang datang langsung ke peternakannya melihat dan memeriksa ternak yang akan diperjual belikan. Hal ini tidak sesuai dengan pendapat Ahmad (2014) menyatakan bahwa kepercayaan dan kemudahan memasarkan produk dapat memberikan kemudahan kepada produsen dan konsumen.

3. Kontribusi Perempuan Tani-Ternak dalam Peningkatan Kesejahteraan

Keikutsertaan perempuan dalam kegiatan usaha peternakan merupakan salah satu upaya peningkatan keamanan ekonomi keluarga dan efesiensi pemanfaatan sumber daya lokal serta meningkatkan status gender perempuan dalam kegiatan sektoral (Abdullah dan Amrawati, 2008).

Berdasaran hasil wawancara bahwa kontribusi yang dilakukan perempuan di Kelurahan Datara mampu membantu dalam hal peningkatan kesejahteraan rumah tangga untuk kebutuhan sehari-hari dan perempuan yang memelihara ternak sapi di Kelurahan Datara memperoleh manfaat pengetahuan berupa cara membudidayakan ternak sapi walaupun hanya secara tradisional, manfaat lain yang didapatkan yaitu meningkatnya kerjasama antara sesama peternak maupun pedagang. Hal ini sesuai dengan pendapat Suradisastra dan Lubis (2000) yang menyatakan bahwa keikutsertaan perempuan dalam kegiatan usaha ternak mampu memberikan bimbingan finansial dalam bentuk peningkatan pendapatan keluarga.

Kontribusi perempuan dalam budidaya ternak sapi potong yang ada di Kelurahan Datara, sangat berperan dalam pengambilan keputusan seperti halnya pembeliaan dan 
pemilihan bibit ternak, penjualan ternak serta pemanfaatan uang hasil penjualan ternak, dalam hal ini peran perempuan lebih mendominasi dalam pengembilan keputusan. Hal ini sesuai dengan pendapat Bonewati (2016), peran perempuan dalam pengambilan keputusan paling menonjol adalah pengelolaan keuangan rumah tangga. Pengelolaan ini mulai dari penyimpanan hingga pengaturan kebutuhan sehari-hari. Hal ini tidak mengherankan karena budaya pada sebagian masyarakat memandang bahwa perempuan lebih mempunyai kemampuan dalam mengelola keuangan rumah tangga.

\section{KESIMPULAN}

Kontribusi perempuan dalam pemeliharaan mengontrol dan memberikan makanan pada ternak sebanyak dua kali sehari yakni pada pagi hari pukul 07.00 WITA dan sore hari pada pukul 16.30 WITA, hal ini mereka lakukan setiap harinya. Namun ada beberapa peternak yang memilih tidak mengandangkan ternaknya, mereka hanya melepaskan di area persawahan dengan tujuan agar ternaknya mampu memenuhi kebutuhan hijauannya. Kontribusi yang dilakukan perempuan di Kelurahan Datara mampu membantu dalam hal peningkatan kesejahteraan rumah tangga untuk kebutuhan sehari-hari dan perempuan yang memelihara ternak sapi di Kelurahan Datara memperoleh manfaat pengetahuan berupa cara membudidayakan ternak sapi walaupun hanya secara tradisional.

\section{DAFTAR PUSTAKA}

Abdullah, A. dan Amrawati, A. 2008. Peranan Istri Petani Ternak Ayam Buras Dalam Upaya Peningkatan Pendapatan Keluarga Di Kabupaten Bulukumba. Fakultas Peternakan Universitas Hasanuddin Makassar. Seminar Nasional Teknologi Peternakan dan Veteriner. Hal. 711-717.

Ahmad, J. 2014. Faktor - Faktor yang Mempengaruhi Curahan Waktu Kerja dalam Usaha Ternak Sapi Potong di Desa Barabatu Kecamatan Labakkang Kabupaten Pangkep. Skripsi. Fakultas Peternakan Universitas Hasanuddin Makassar.

Bonewati, Y. I., 2016. Peran Perempuan Pada Usaha Ternak Sapi Potong Yang Terintegrasi Dengan Tanaman. Skripsi. Jurusan Sosial Ekonomi Peternakan. Universitas Hasaniddin, Makassar.

Mahmuda, N. 2015. perempuan dalam tantangan Modernitas. Jurnal An-Nisa', Vol.8.

Mariyono., Anggraeni, Y., Rasyid, A. 2010. Rekomendasi Teknologi Peternakan dan Veteriner Mendukung Program Swasembada Daging Sapi (PSDS) Tahun 2014. Badan Penelitian dan Pengembangan Pertanian 
Putra, E. T. 2014. Analisis Kualitas Layanan Terhadap Tingkat Penjualan Produk Telkomsel Dioutlet N dan X Cell. Jurnal Apresiasi Ekonomi, 2(2).

Rianto dan Purbowati. 2009. Panduan Lengkap Sapi Potong. Penebar Swadaya, Jakarta.

Siregar, 2008. Penggemukan Sapi Jakarta. Penebar Swadaya, Jakarta.

Suradisastra, K. dan Lubis, A. 2000. Aspek Gender Dalam Kegiatan Usaha Peternakan. Pusat penelitian Sosial Ekonomi Pertanian. Bogor. Jurnal Wartazoa, 10 (1), 13-19. 